\title{
Prologue: Skirting the Ethical
}

Kein Mensch muß müssen.

No one must must.

—Lessing, Nathan der Weise

\section{What If ...}

What could such disparate texts and films as those read here, Sophocles' Antigone, Plato's Symposium and Republic, Hamann's "Aesthetica in nuce," Sebald's The Emigrants, and Campion's The Piano, possibly have in common? Spanning multiple genres and thousands of years, they initially find their place in classical antiquity, but with subsequent leaps move first to the eighteenth and then to the twentieth century, from Greece to Germany and then to New Zealand. Is it irreponsibility, then, that nevetheless gathers them together under the same cover? This would be a cover, after all, that fails to concentrate them into a single shape and under which, admittedly, all conclusions remain enmeshed in the intricacies of individual moments.

Even if it will not ultimately cover for them, it is impossible to miss the ethical call in each of these works, above all these works, so noted for their political and ethical positionings. Thus Antigone, challenging the rule of state, eloquently commits herself to the perfect divine law. The Republic images the ideal state and famously offers both a definition of justice and a meditation on "the good." Socrates culminates his speech in the Symposium by guiding the listener to "true virtue" destined to make one beloved by the gods (212a). In "Aesthetica in nuce" Hamann, too, invokes the name of his god, speaking in the name of Jesus Christ and closing that essay with a celebration of the Last Judgment. "The Piano" rehearses an immediately recognizable array of politically correct admonitions. And who 
could miss the moving and somber call to conscience of Sebald's narrator who brings us face to face with the Holocaust? No consideration of these works can avoid coming to terms with their leap-to-the-eye pronouncements. Taking them seriously, as they lie at the very crux of the matter, is where all understanding begins.

Yet, what if ethics were neither prescription nor action-even though this is the defintion of ethics from which one will never entirely escape? And, perhaps, rightly so. What if, in the most striking manner, major works of Western letters, even those most celebrated for taking an ethical and political stand, perform a resistance to just this understanding of it? How could one conceive an ethics that is not prescriptive, in which language does not simply tell us what to do? What if an ethics practiced by these writings as an act of resistance functions neither as prescription, simply, nor as its negation? What if this other version of ethics is bound to jam what traditional ethics presupposes about language, both language in general and the medium of its message? What if such disruptions were not the failure of the ethical but rather the beginnings of a redefinition of it as responsibility, another display of it, a nontyrannical ethical no longer irrevocably bound to a must? What if, precisely in those works we turn to, say, for a definition of the state or of the good (Plato's Republic, for example), or that we regard, on the other hand, as among the most noble and heroic challenges to state tyranny (Sophocles' Antigone, for example), something else is in question? What if this challenge were necessarily an affront to the exemplarity of these works, no matter how often we call on them to serve in that guise? What if at a certain juncture they refuse to serve as examples, so different is the particularity of their configurations on these issues? What if ethics is abruptly and punctually shifted in these works from the realm of the eternal must be to an ever renewed and ever new call that asks: What if?

\section{The Language of Ethics . . .}

Still, in another sense, one cannot but encounter the ethical head on. What could be more evident? It establishes boundaries, sets forth in a gesture of well-marked difference limits that must not be transgressed. What, if not the ethical, could we trust to speak to us straight out, couched in a language that says what it means, shining directly (like the sun that stands in for the good in Plato's famous passage) as the necessity of the must-or 
at least of the should be, the value of the good and the true? And if that is the case, if there is an ethical gravity to all these texts that seems to concentrate each individually into a single, graspable shape, a shape that makes them generalizable in turn as works about the ethical, this is a gravity which we dare not give in to, not now, not yet, even though it is most certainly what they are about.

We read here works that openly stake out ethico-political positions, but are no less bound to disrupt them. Six works that set up side by side, as parallel worlds, literal and letteral tyrannies: the power of the state, polis, or Reich, of patriarchy, of divine law and its unshakable judgment, for example, alongside unproblematic powers of representation ${ }^{1}$ and prescription. Six works that at the same time skirt their own prescriptions, ethical and linguistic, by way of meditations that may, as in Plato and Hamann, speak directly about language, but which more incisively perform its complexities and thus question their own will to unmediated truth and moral certitude.

For, actually, there is also no way to avoid skirting the ethical. All direct hits turn out suspicious at best. Hitting on it won't do at all-except, perhaps, in the shadows, where Socrates, groping about, claims to find it in the form of justice (Republic, IV, 432b-e). However, as even he would ultimately admit, that still tends to leave us in the dark. Not that skirting the issue-what the chapters that follow inevitably perform-will lead to enlightenment. Not one of these essays can make that promise. Still, following where the texts meander, tracing their indirections, while cognizant, at a respectful distance, of where they more obviously lead, produces versions of the ethical and political critical to their understanding. Thus we will listen to the shrieks of birds in Antigone and the freakish clicks of a metal finger on keys in the The Piano. We will take the drunken Alcibiades at his word in the Symposium. We will resist the rapacious dialectic of Socrates, the drive to represent and recuperate in The Emigrants, and the strangely paired seductions of scholarly reference and theological judgment in "Aesthetica in nuce."

Conventional ethics takes form here, then, as (and is therefore implicitly bound to a concept of) language capable of saying what it means more or less directly and operating as a call to action. There is, however, another version of the ethical. It doesn't say what it has to say head-on. And yet this act of skirting is neither tangential, nor beside the point. It is precisely this mode of indirection that challenges the potential tyranny of 
an ethics that threatens to become unquestioned compulsion. This other version is at work in these texts-not as the definitive undoing of the straightforward ethical positioning-but as its disturbance. ${ }^{2}$

Parallel to the admonitions about what not to take at face value in Sophocles, Plato, Hamann, Sebald, and Campion, another is in order about what not to take seriously in the essays that follow. It is not a question of introducing another moment, another passage, another text, in order to substitute it for those openly assured ethical proclamations. Whatever is staged here, these are not rhetorical struggles with winners and losers. Alcibiades enters when Socrates has finished speaking, but his speech (to which our reading will turn) does not have a life all its own. Campion's film, we will emphasize, closes with no fewer than three endings, but we cannot settle for simply disregarding the apparent moral of the first with the onslaught of the others. And its final complex moments do not drown out the echoes of what precedes: they enter into relation with it. Hamann's essay cites an earlier work, the Biblical Observations, but the crisis there generated does not stand in place of "Aesthetica in nuce." It is not a matter of countering the ethics for which these texts evidently speak so much as of allowing, however indirectly, an ethics of another order, an ethics which is, to be sure, out of order, to erupt or break through as part of the picture. At a critical point in the Republic Socrates speaks of having to settle for the paradeigma, which we have written of as the side-by-side. And whereas Socrates may imply that the side-by-side is a compromise, it is that splaying, the dislocating disassemblage of irresolvable alternatives, that opens up a certain hope, the hope of emancipation from an otherwise inevitable absolutism of sorts.

The reader, then, should be wary of the somewhat triumphal tone that finds its way into several of the commentaries that constitute this book, tellingly at their close. There are suggestions (perhaps necessary, in any case strategic) of resistance, liberation, interruption, as "respons-ability," arriving at the last possible moment to transform what came before. These should not be taken as the decisive word. If something like liberation or response is at stake, no endgame is at hand. It must rather be thought as a force at play more or less throughout. Thus if patriarchy is famously at stake in Sophocles' tragedy, what challenges is not a matri-archy that, mimicking the enemy, becomes its other, the double that would reinstate power under another name and another gender. The motherhood at issue in Antigone does not trump the old regime so much as disturb it. It side- 
steps or skirts the lineage and power of reproduction and sashays toward an ethics without chain of command. What kind of ethics could this be that doesn't go by the rules but rather goes by them and goes on to upset the ruling, that offers us no definitive shape, no pure idea, no absolute good, no access to heaven after all, no promise of spoils, no reassurance of source, no final judgment? And which, all that notwithstanding, is certainly no call to anarchy.

Moreover, why should the strange paths of these texts that both hit upon and also veer off from the most conventional modes of asserting the ethical and political pass by way of issues of language that could seem so very beside the point? Why do both the texts read as well as the commentaries that make up this book skirt and flutter by the gravity of a definitive ethics precisely while confronting an unsettling coming to terms with language? Thus, to give some singular examples: Socrates will celebrate the dialectical mode of argument, shaking himself loose from his earlier method of eristics. The mode of speaking is anything but irrelevant, for the city they are forming, he will remind his followers, is a city they make in speech. And the attributes of dialectic, the rules of its game, will prove entirely at one with the political aim, the polis they see taking form. Or, in Hamann's "Aesthetica in nuce," every reader is confronted with the opacity of a text that begs for the scholarly labor of footnotes to lead us to the spoils of obscure and hard-won points of reference. Those same scholars who undertake this task liken Hamann's text to typology, thus attributing to his linguistic form the theological promise of redemption which is also at stake in the content of his essay. In Campion's The Piano which so often comments on its own filmic materialism, the language of its representation is time and again linked to ethical crises. We view, for example, the performance of Bluebeard, a play with a pointed moral that parallels the plot of the film, in which the complexities of its staging confuse an audience into taking it as a call to ethical action. How shall we conceive the analogies among a conservative theorization and practice of language as communication, an ethics that compels, and the imposition of a politics based on identity?

I have traced the unnameable state of affairs in these texts, in which the disturbance of comfortable linguistic modes is oddly productive of the ethical and political, under many names: in Plato as figuration (Symposium) or analogy (Republic), as "living underwater" and the filmic in The Piano, in The Emigrants as "cross-pollination" and the disruption of 
contained delineation. For the renegade ethics toward which these works point, but which can never be isolated or approached directly, are caught up in ungovernable versions of representation. Ungovernable-which is not to say precisely that they overcome the rule of law. That conventional structures of representation cannot reign marks, not the failure of the ethical, but the opening toward, the (however tentative) eruption, into an emancipation from the must be. Perhaps this begins to explain that strange interjection in the exemplary work of German literary ethics, Lessing's Nathan the Wise, which forms the epigraph of this prologue: for how can it be that Nathan, that figure of wisdom, insists, in however offhand a manner, that no one should be compelled to "have to." "Kein Mensch muß müssen." What kind of an ethics is it that sheds the "must"?

\section{Skirting Identity and a Call to Judgment}

There is also that other sense of "skirting," toward which the heavyhanded pun of the book title reaches. For the political and ethical gestures read here are sometimes overtly and often famously bound up with the question of gender. Jane Campion's film, The Piano, is to all eyes, at least from a certain point of view, a feminist film if ever there was one. Hamann's best known work, "Aesthetica in nuce," directs us to a little celebrated corner of his opus in which the definitions of good and evil pivot around the virtue of a biblical heroine. The Symposium is conditional upon expelling women from the scene of discourse, though Socrates, in a speech which one tends to take as Plato's final word in the matter of love, ventriloquizes his female mentor. In the Republic we find Socrates forced to turn back and transvaluate the place of woman in the polis before his ideal state can be fully conceived (Book V). It is gender politics as well that are so often understood to govern Antigone's affront to the state: by Creon in the tragedy and by many of Sophocles' most striking readers-Hegel and Irigaray, for example-for whom the formation of the state and the ethical in general cannot but pass by way of woman.

In both Plato and Hegel one has to domesticate woman in order to establish the state. Socrates solves the problem by taking her into the polis on an almost equal footing. Hegel, repressing the power of "womankind" as the eternal irony of the community, declares her, along with the family, a mere steppingstone on the way to the state. Having accounted for 
the gender war, both Plato and Hegel are thereafter, however, unable to imagine a state without acts of aggression that define its borders with a barbarian other. Woman, it seems, was something of a place holder for a more generalized structure of otherness.

If in Plato and Hegel identity in the name of gender drifts to identity in the name of state, Sebald has a sense of their uncertain ground. He turns all this inside out or, perhaps better, blurrs it. For, at least in The Emigrants, and however obliquely, Sebald walks a very fine line when it comes to identity politics. History positioned him to do something different. That he skirts the issue of the Holocaust, even as he invokes it, is what one all too readily chooses not to see. Coming to consciousness in a postwar Germany where the "other" had been all too effectively eradicated, he writes less of discord with or war against the foreign than of the inevitabilities of its aftermath. The enigmatic photos that riddle his texts have everything to do with his enterprise, and everything to do with their misunderstanding. These are documents of restoration, recuperation-reparations of sorts but also, in a final turn, as we shall see, of self-accusation: the accusation that the attempt to memorialize, to reinstate, might place the narrator in the position of a very different politics, one that identified, not in order to recover, but rather to differentiate and annihilate. Sebald's is a rare, if indirect, meditation on the difficult relationship among representation, identity, aggression, and the inadequacy of be good-feel good ethics, of the necessity of perpetual renegotiation of identity as well as truth. Identity, politics, ethics, the language of representation: they are not the same but they are all put into relation with one another, shot through, preoccupied, animated, and haunted by similar forces and issues.

Let us dwell for a moment on that final turn. Nowhere in Sebald's writings is the flickering function and danger of representation more striking than in the closing lines of The Emigrants. Alone in a room, the narrator resurrects the experience of seeing a photographic exhibition about the Litzmannstadt ghetto. He brings back in words (the image itself is not reproduced) the faces of three women weaving at a loom. He imagines how they might have been called. Could they be "Roza, Lusia, and Lea," prototypical Polish given names? or rather "Nona, Decuma, and Morta," the Parcae or fates of Roman mythology — with spindle, and thread and scissors? What takes place as one shifts from one set of musings to an- 
other, from the conjectured specificity of the first to the mythical power of the second? Sebald's text which has seemed so bent on bringing back the dead, on saving the ghostly sufferers of the past, a text that bolsters its meanderings in this endeavor with photographs from albums, newspapers, and goodness knows where, deadends in an image. It positions him as the ghetto photographer, an official obsessed with memorializing his own " good" works in service to the Nazi regime. The narrator who sets out, more or less, to wed himself with the woman in the middle (she was, he writes, somehow like a bride) and save the imaginary "Roza, Lusia, and Lea" stands challenged: first by a gaze from the photograph and then by the Fates, judged for repeating the act of re-production, representation: the savior become perpetrator. The narrator's life, his fate, his death are at stake, as is the significance of his textual endeavor in which the politics of identity cut both ways. Sebald observes his alter ego seeing and being seen-the viewer scrutinzed, accounted for, summed up. His watchfulness about representation and judgment calls for ours.

It is unsettling to come to terms with how the one becomes the otherthe impassioned attempt to save that seems to drive not only the Emigrants but Austerlitz and much else in Sebald's work as well, transfigured into an object of critique. More troubling still, there is no easy way to account for the act of judgment itself. Is it the promise of calculable justice as in the Republic's myth of Er, or is it an act of unjustified violence-or something else again? How to understand the limits of judgment, those it necessarily sets, its inevitable shortcoming, as well as its inevitability? And what does it mean to marginalize judgment in the name of liberation (as the essays that follow may seem to do), when it is precisely another version of judgment at the close of The Emigrants that successfully ruptures the narrator's ethical complacency? Are telos and interruption, perhaps, not so clearly distinguishable after all?

At the interruptive close of "Aesthetica in nuce" Hamann appends what he calls an "Apostille," a gloss, a critical commentary, marginalia to his text. It doesn't upend what came before so much as warn us of its vanity, while calling upon us as well to read more and read elsewhere in order to understand the critical insights of what he has been about. It is a refusal of the tyranny of unexamined language, a refusal of thought to settle. His is an admonition and an explanation after the fact. I put mine up front. That language is always articulated with—or, as we have said, productive of - the political and ethical is difficult to make out, if only because it for- 
mulates no-thing definitively. What follows is not a vigil over the defunct body of ethics so much as a bid for vigilance as the difficult practice of reading. ${ }^{3}$ Perhaps at least this much is legible: if the ethical is something to be desired, we find ourselves perpetually compelled to revisit the interrelation among ethics, the political, and the specificities of individual acts of interpretation, however illusive the spoils of such a struggle might be. This is the risk of every judgment call while also a call to judgment. 

SKIRTING THE ETHICAL

$\longrightarrow$ 
